\title{
Evaluation of Molecular Response to Imatinib in Iraqi Chronic Myeloid Leukemia Patients Using Real Time - Reveres Transcriptase-Polymerase Chain Reaction (RT-RT-PCR) - Taqman Assay
}

\author{
Maysaa Abdul Razzaq Dhahii (Corresponding author) \\ Microbiology Department/College of Medicine, Al-Nahrain University \\ PO box 70062, Al-Kadhmiya, Baghdad, Iraq \\ Tel: 964-7901-736-316 E-mail: mayssa_ares@yahoo.com
}

Nabeel S. Murad

Internal Medicine Department/College of Medicine

Al-Nahrain University, Iraq

Tel: 964-7901-366-619 E-mail: nabeelmurad@yahoo.com

Bassam F. Matti

Hematology unit - Baghdad teaching Hospital- Medical city, Iraq

Tel: 964-7702-052-345 E-mail: bassam_francis@yahoo.com

Received: May 9, 2011 Accepted: May 24, $2011 \quad$ Published: December 31, 2011

doi:10.5539/jmbr.v1n1p47 URL: http://dx.doi.org/10.5539/jmbr.v1n1p47

\begin{abstract}
Real-time quantitative (RQ-PCR) assays were developed to monitor the kinetics of residual BCR-ABL transcripts over time and to follow up chronic myeloid leukemia patients (CML) treated with imatinb mesylate (IM) for assessment of response at different IM treatment durations.

This is a prospective study enrolled 135 patients at The National Center of Hematology (NCH) /Al-Mustensseria University from February 2006 to August 2008, in addition to 25 healthy individuals consider as health negative control. Only 42 patients were could be followed up regularly. From them, only 40 venous blood (VB) samples related to $20 \mathrm{CML}$ patients (collected at different intervals from starting IM treatment) were give sufficient extracted RNA that could be use in PCR reaction. Quantitative analysis using Real time-Reverse Transcriptase-PCR (RT-RT-PCR) was done for each patient at two different time points of IM treatment duration.

The results of RT-RT-PCR reaction were recorded as ratio between transcripts of bcr-abl /abl $\times 100$ at these two time points of analysis. The mean values of ratio at first and second time points of analysis were $(0.879)$ and (0.471), respectively. There was a statically significant difference $(p=0.05, \mathrm{LSD}=0.0324)$. Also, RT-RT-PCR results were recorded as log reduction of bcr-abl transcripts. There is no significant differences in the percentage of patients who achieved complete molecular response (CMR) ( $\geq 4 \log$ reduction) and major molecular response (MMR) (3 log reduction), but there is a significant differences in the percentage of patients who achieved only Minor-MR $(2 \log$ reduction) $(\mathrm{p}=0.05, \mathrm{LSD}=13.789)$ and patients who not achieved $\mathrm{MR}(<2 \log$ reduction $)$ $(\mathrm{p}=0.05, \mathrm{LSD}=5.779)$.

Quantification molecular analysis using RT-RT-PCR is essential tool for assessment of molecular responsiveness to imatinib because it is most specific in discriminating between response subgroups of patients than cytogenetic analysis.
\end{abstract}

Keywords: CML, Imatinib, Bcr/abl, Real time Reverse Transcriptase PCR 


\section{Introduction}

Chronic myeloid leukemia (CML) is a stem cell disorder result from chromosomal abnormality, Philadelphia chromosome $(\mathrm{Ph})$, which arises from the reciprocal translocation of part of long arm of chromosome 9, where proto-oncogene $\mathrm{ABL}$ gene (Ablson) is located, to long arm of chromosome 22, where BCR gene (Break point Cluster Region) is located forming BCR-ABL fusion gene, a molecular marker of CML (O'Brien et al., 2009). Depending on the breakpoint in bcr, there are three forms of bcr-abl fusion gene. Breakpoints in the Major-bcr region (M-bcr) of the bcr gene result in fusion of the second or third exon of this region (b2, b3) with the second exon of the abl gene (a2) to form the $\mathrm{b} 2 \mathrm{a} 2$ or $\mathrm{b} 3 \mathrm{a} 2$ transcripts which encodes the p210 hybrid protein . Breakpoints in the miner-bcr region (m-bcr) of the bcr gene result in fusion of the first exon of this gene (e1) with the second exon of the abl gene (a2) to form e1a2 bcr-abl transcript which encodes the p190 hybrid protein. Breakpoints in the micro-bcr region ( $\mu$-bcr ) of the bcr gene juxtapose the exon 19 (e19) of this gene to the second exon of the abl gene (a2) to produce the e19a2 transcript which encodes the p230 protein (Radich et al., 2009; Quintas-Cardama et al., 2009; Jabbour et al., 2009; Quintas-Cardama \& Cortes, 2009).

The suppression of BCR-ABL is likely to be crucial for therapeutic success. By late 1980s, synthetic competitive inhibitor of ATP tyrosine kinase binds to ATP -binding site of tyrosine kinase domain in BCR-ABL protein was developed. The development of the BCR-ABL-targeted Imatinib mesylate (IM), that selectively toxic to cells expressing the constitutively active $\mathrm{BCR}-\mathrm{ABL}$ protein tyrosine kinase and not normal progenitors, represents a paradigm shift in the treatment of CML (Shi et al., 2009).

Imatinib induces hematological, cytogenetic and molecular remission in CML patients in chronic phase. However, there are still estimated residual leukemic cells which carry fusion gene and this can lead to molecular relapse, which precede hematological and cytogenetic relapse by median of six months. Subsequent experiments showed that continued exposure to IM for CML patients is necessary to eradicate the tumor or to maintain the complete molecular response in the absence of resistant mutations (O`Dwyer et al., 2001).

The correct monitoring of treatment of CML, which nowadays comprises assays of IM as well as cytogenetic and molecular evaluation of residual disease and the search for cABL kinase domain mutations, should be performed at regular intervals (Baccarani et al., 2006; Hughes et al., 2006).

Quantitative Real-time PCR (QRT-PCR) has become a robust basis for routine therapeutic decisions (Gabert et al., 2003). However, a considerable number of patients have been reported to show resistance to IM, leading to relapses. Resistance against IM has been attributed mostly to mutation in the ATP- binding site of tyrosine kinase domain of the bcr-abl which lead to conformational changes in BCR-ABL protein resulting in impairment of IM binding(Ayalew et al., 2005; Stephanie et al., 2005; Ramirez \& Dipersio, 2008).

The purpose of present study was to apply molecular technique such as reverse transcription - real time -polymerase chain reaction in monitoring minimal residual leukemia cells in IM treated CML patient's blood samples in order to assess the responsiveness to IM.

\section{Research Methods}

\subsection{Patients}

This is a prospective study enrolled 135 patients at The National Center of Hematology (NCH) /Al-Mustensseria University from February 2006 to August 2008. They were diagnosed clinically, hematological and cytogenetically as CML. From those patients, only 42 patients could be regularly followed up for samples collection every (3-6) month and they diagnosed molecularly as CML by monitoring for the presence and the type of bcr-abl fusion gene (a2b2, a3b2 or e1a2) using Multiplex-Single Step-Reverse Transcriptase-Polymerase Chain Reaction (M-SS-RT-PCR). All of those patients were bcr-abl/a2b2 positive. Patients were randomly selected concerning to age, gender, disease duration, disease phase and pre-treatment.

From 90 VB samples, only 40 VB samples related to 20 patients(collected at different intervals from starting IM) were give extracted RNA with a sufficient quality that could be used in PCR reaction. The characteristics of those 20 CML patients were shown in Table 1.

Twenty five healthy individuals were included as healthy negative control. They were evaluated hematological, cytogenetically and molecularly in the same manner as the CML patients.

Commercially available extracted RNA from BCR-ABL cell line K562 (Ambion,USA) was used as a positive controls in molecular experiments.

One $\mathrm{ml}$ of VB sample was obtained from each subject, placed in tube containing EDTA (as anti-coagulant) and kept at $-80{ }^{\circ} \mathrm{C}$ until used. 


\subsection{RNA extraction}

Total RNA was extracted from $100 \mu \mathrm{l}$ VB using BD tract RNA /DNA isolation kit (maxim Biotech, USA) following manufacturer information. RNA concentration and purity were estimated according to Sambrook et al. (Sambrook et al., 1989) using UV-spectrophotometer (CECIL, CE 7200). The integrity of RNA was checked by size fractionation using formaldehyde agaros gel electrophoresis (Sambrook et al., 1989).

\subsection{First strand cDNA syntheses}

First strand cDNA was synthesized using the following procedure: The first master mix (MM-1) was prepared by mixing the following components (per one reaction): $1 \mu \mathrm{l}$ from $500 \mu \mathrm{g} / \mathrm{ml}$ Random hexamer primer (promega, USA), $1 \mu \mathrm{l}$ of dNTPs $(200 \mu \mathrm{M}$ each) (promega, USA), RNA (final concentration $1 \mu \mathrm{g}$ ) and DEPC-H2O to final volume $13 \mu \mathrm{l}$. The mixture was heated to $65{ }^{\circ} \mathrm{C}$ for $5 \mathrm{~min}$ and incubated on ice for at least $1 \mathrm{~min}$. The second master mix (MM-2) was prepared by mixing the following components (per one reaction): $4 \mu 1$ from $5 \mathrm{X}$ first strand buffer(invitrogen, USA), $1 \mu \mathrm{l}$ from $0.1 \mathrm{M}$ DTT (invitrogen, USA), $1 \mu \mathrm{l}$ from $40 \mathrm{U} / \mu \mathrm{l}$ Rnase Inhibiter (invitrogen, USA)and $1 \mu 1$ from (200U/reaction) Superscript 111 reverse transcriptase enzyme (invitrogen, USA).

The second master mix was added to MM-1 and the components were mixed by pipetting gently. Reaction tubes were incubated at $50{ }^{\circ} \mathrm{C}$ for $50 \mathrm{~min}$ then, heated at $70{ }^{\circ} \mathrm{C}$ for $15 \mathrm{~min}$. Synthesized cDNA was used directly in PCR reaction or stored at $-20{ }^{\circ} \mathrm{C}$ until used.

\section{4 cDNA quality assay}

In order to estimate the integrity of cDNA, it was amplified using primer set specific for housekeeping gene, Glycerol aldehyde phosphate dehydrogenes (GAPDH) (Barbany et al., 2000). Figure 1 shows the results of agaros gel electrophoresis of amplified products of GAPDH gene. Only single bands with molecular size about $600 \mathrm{bp}$ were detected. That indicated a sufficient synthesis of cDNA.

\subsection{Real time -RT-PCR (RT-RT-PCR) using Taqman assay}

The BCR-ABL Mbc fusion Quant kit (Ipsogen, France) was used for the accurate quantification of BCR-ABL P210 transcripts following the manufacturer information and using iCycler iQ Multicolor Real-Time Detection System (Bio-Rad, USA). The results were recorded as ratio between transcripts of bcr-abl /abl $\times 100$, and as $\log$ reduction at two time points of analysis. Also, the results were recorded as cycle threshold of bcr-abl and abl.

Figure 2 shows log reduction of bcr-abl transcripts at first and second time points of analysis.

\subsection{Test interpretation}

To determine the precise amount of target present in the tested samples, a standard curve was established using standards with a known number of molecules. Results are relative to 100ng of total RNA corresponding to $5 \mu$ of the reverse transcriptase reaction.

\subsection{Statistical analysis}

The General Linear Model (GLM) method within the Statistical Analysis System-SAS (2001) program was used to study the factors effect (time) in the some trails. Least significant difference (LSD) test was used to the comparison between means.

\section{Results}

\subsection{Patient's Demography}

The overall mean age of CML patients at diagnosis were $34.71 \pm 1.02$ years with a range (9-70) years. The highest percentage of CML patients was occurred between (20-29) years. The male to female (16/26) ratio was 1:1.62. No family history with CML was seen.

The mean ages of healthy individuals included in this study as CML negative control were 42.13 years, ranging from (27-75) years. Also, the male to female ratio was 1:1.4.

\subsection{Determination of bcr-abl ratio using RT-RT-PCR}

Quantitative analysis was done for each patient at two different time points of IM treatment duration. The mean of IM treatment duration for those patients at first and second time points of analysis were 23.1 months and 35.95 months, respectively. The mean values of ratio at first and second time points of analysis were 0.879 and 0.471 , respectively. There was a statically significant difference $(\mathrm{p}=0.05, \mathrm{LSD}=0.0324)$.

The results of RT-RT-PCR reaction according to log reduction shows that there is no significant differences in the percentage of patients who achieved complete molecular response (CMR) ( $\geq 4$ log reduction) and patients who achieved major molecular response (MMR) (3log reduction), but there is a significant differences in the 
percentage of patients who achieved only minor molecular response (Minor-MR) (2log reduction) $(\mathrm{p}=0.05$, $\mathrm{LSD}=13.789)$ and patients who not achieved $\mathrm{MR}(<2 \log$ reduction) $(\mathrm{p}=0.05, \mathrm{LSD}=5.779)$.

Also, the results could be studied as Ct of bcr-abl and abl. The mean of Ct value of bcr-abl and abl in tested samples were (35) and (32), respectively. The limit of this manner to express quantitative results is that it is related to the quality of the RNA analyzed. The slop value and the efficiency value of the standard curve through different reactions ranging between (-3.4 to -3.3$)$ and (88 to 100), respectively.

In this assay, K652 cDNA was used as a positive control (and for evaluation between-run and within-run reproducibility).The $\mathrm{Ct}$ value of bcr-abl and abl were (22) and (21), respectively, in each time used and that closely consistent with what mentioned in the manufacturer catalog (Ipsogen, France).

Healthy individuals tested as CML negative controls scored completely as negative for this assay.

\section{Discussion}

With the recent advent of newer therapies, such as the tyrosine kinase inhibitor, IM, molecular monitoring has become indispensable for assessment of patient's therapeutic response and early detection of relapse. For patients who develop acquired resistance to IM, therapeutic strategies have been developed to overcome such resistance. Conventional RT-PCR that generates only positive or negative results does not allow timely assessment of therapeutic response because many patients remain positive for a long period even after they achieve a cytogenetic response. In contrast, quantitative assessment of bcr-abl transcripts using real-time technology has become the method of choice. It has been proven as a clinically useful test because patients with high or increasing levels of bcr-abl over the disease course have a greater probability of relapse than those with steady-state or decreasing levels of BCR-ABL (Kantarjian et al., 2008).

In this study, bcr-abl transcripts level was monitored in $20 \mathrm{CML}$ patients treated with IM for determine molecular response to IM and studying the correlation between bcr-ab transcript level and HR, CyR, IM treatment duration, IM dose and gap in IM treatment.

Two CML patients were achieved CMR (4 log reduction) (bcr-abl not identified repeatedly). They had a good prognosis. They were in chronic phase from diagnosis until the end of the study, treated with IM as a first line treatment, had no gap in treatment, achieved CHR after starting IM by one month and along the study and also achieved MCyR along the follow up period. One patient achieved MMR ( $3 \log$ reduction) after $8 \mathrm{~ms}$ in IM treatment and still in this level of molecular response after $25 \mathrm{~ms}$ (at the end of this study). Also, this patient had a good prognosis. Most patients included in this assay had achieved Minor-MR (2 log reduction). The highest percentage of them were achieved only PHR and PCyR. Also, those patients had gaps in treatment. Patients who did not achieved MR $(<2$ log reduction) were in AP without any HR or CyR, even IM dose was escalated to $800 \mathrm{mg} /$ day for $8 \mathrm{~ms}$.

Cortes et al. (2004) reported that patients who achieved a major molecular remission by 12 months after the start of IM had an improved probability of a sustained MCyR. In other study, it showed that not only patients achieving a major molecular remission at 12 months is predictive of a durable cytogenetic remission but also those patients who achieved a major molecular remission already at the time of first achieving CCyR or MCyR have significantly longer cytogenetic remission durations than those without this magnitude of molecular response. Also, such patients had a high probability of progression-free survival (Martinelli et al., 2006).

Similar results were obtained by a prospective randomized trial called 'IRIS', which enrolled 1106 newly diagnosed CML patients(Hochhaus et al., 2002). Smaller-scale studies on patients treated with imatinib showed a strong correlation between the percentage of $\mathrm{Ph}+$ metaphases and BCR-ABL levels as measured by Q-PCR (Kantarjian et al., 2008) .

In all these studies it is too early to understand what level of molecular response can be used as an indication of long term disease control and more research is needed before it can conclude whether 'molecular responses' are of long term prognostic value in terms of cytogenetic response in imatinib-treated patients.

The definition of molecular responses is still evolving. It was considered that a major molecular response as reaching an absolute value of bcr-abl ratio $(\leq 0.0005)$, a value that has been found predictive of duration of cytogenetic response. The terms 'PCR negative' and 'complete molecular response' should be used with caution. They imply an absolute lack of measurable leukemia, which may be misleading. Also, there is inherent variability in the sensitivity of QRT-PCR assay between laboratories and between samples (Iacobucci et al., 2007).

In this study, ABL gene was used as a control gene. Suitability of choice control gene was evaluated by 
amplifying cDNA from K652 (as positive control) that give an expected value as referred by kit manufacturer catalog .ABL gene is probably the most widely used normalization control for BCR-ABL quantification in Europe and North America. The European Against Cancer (EAC) study has evaluated several commonly used control genes and concluded that $\mathrm{ABL}$ is the most suitable one.

Because quantitative of bcr-abl is primarily used in patients who have been treated for CML to estimation their response to therapy, the bone marrow or peripheral blood from those patients typically contains normal hematopoietic cells in addition to residual CML cells. A key criterion for a suitable control gene should be that it is expressed in CML cells at a comparable level to that in non-CML cells, so that the level of the control gene ultimately reflects the amount of total RNA being analyzed irrespective of the CML-to-non-CML cell ratio in the mixture.

In this study, this issue was evaluated by mixing $(2.5 \mu \mathrm{l})$ of K562 cDNA with $(2.5 \mu \mathrm{l})$ of healthy individual cDNA in one reaction tube and the result of this reaction was compared with that of K562 alone in the same run. No difference was seen in bcr-abl ratios between these two amplified products.

It is currently recommended that IM therapy be continued indefinitely. Anecdotal reports suggest that the discontinuation of IM, even in patients with undetectable levels of BCR-ABL transcripts, results in relapse. Although it is not known why IM is not able to eradicate the malignant clone, potential mechanisms include drug efflux, amplification or mutation of the BCR-ABL gene may be the cause. It is also possible that imatinib cannot completely inhibit BCR-ABL kinase activity; low levels of activity would allow cells to survive in a quiescent state. As an alternative, the malignant clone could persist through mechanisms that are independent of the BCR-ABL kinase (Breccia et al., 2006; Thomas et al., 2008).

\section{Acknowledgments}

We gratefully thank Dr. Ali Muslim Al-Ameri, National Center of Hematology, Al-Mustensseria University, for his endless support, and for providing excellent working facilities in the National Center of Hematology.

We thank Dr. Abdalla Awidi, Mss.Nidaa Ababneh and Dr.Said Ismail- Molecular Biology Lab/College of Medicine/Jordanian University for their cooperative regarding molecular sides.

\section{References}

Ayalew T., Gordon W. D. \& Mark L. L. (2005). Chronic Myeloid Leukemia: current application of cytogenetic and molecular testing for diagnosis and treatment. Mayo Clin Proc, 80, 390-402. http://dx.doi.org/10.4065/80.3.390.

Baccarani M., Saglio G. \& Goldman J. M. (2006). Evolving concepts in the management of chronic myeloid leukemia: recommendations from an expert panel on behalf of the European Leukemia Net. Blood, 108, 1809-1820. http://dx.doi.org/10.1182/blood-2006-02-005686

Barbany G. \& Hagberg A. (2000). Manifold-assisted reverse transcriptase-PCR with real-time determination for measurement of the BCR-ABL fusion transcript in chronic myeloid leukemia patients. Clinical Chemis, 46, 913-920.

Breccia M., Diverio D. \& Pane F. (2006). Discontinuation of imatinib therapy after achievement of complete molecular response in a $\mathrm{Ph}+\mathrm{CML}$ patient treated while in long lasting complete cytogenetic remission (CCR) induced by interferon. Leuk Res, 30, 1577-1579. http://dx.doi.org/10.1016/j.leukres.2006.03.011

Cortes J., O'Brien S. \& Kantarjian H. (2004). Discontinuation of imatinib therapy after achieving a molecular response. Blood, 104, 2204-2205. http://dx.doi.org/10.1182/blood-2004-04-1335

Gabert J., Beillard E. \& van der Velden V. H. (2003). Standardization and quality control studies of real-time quantitative reverse transcriptase polymerase chain reaction of fusion gene transcripts for residual disease detection in leukemia-a Europe Against Cancer program. Leukemia, 17, 2318-57. http://dx.doi.org/10.1038/sj.leu.2403135

Hochhaus A., Kreil S. \& Corbin A. S. (2002). Molecular and chromosomal mechanisms of resistance to imatinib (STI571) therapy. Leukemia, 16, 2190-2196. http://dx.doi.org/10.1038/sj.leu.2402741

Hughes T. P., Deininger M. \& Hochhaus A. (2006). Monitoring CML patients responding to treatment with tyrosine kinase inhibitors-Review and recommendations for harmonizing current methodology for detecting BCR-ABL transcripts and kinase domain mutations and for expressing results. Blood, 108, 28-37. http://dx.doi.org/10.1182/blood-2006-01-0092 
Iacobucci I., Galletti L. \& Amabile M. (2007). Monitoring BCR-ABL transcript levels by real-time quantitative polymerase chain reaction: a linear regression equation to convert from BCR-ABL1ABL ratio. Hematol, 92, 429-430.

Iacobucci I., Galletti L. \& Amabile M. (2007). Monitoring BCR-ABL transcript levels by real-time quantitative polymerase chain reaction: a linear regression equation to convert from BCR-ABLIABL ratio. Hematol, 92, 429-430.

Jabbour E., Kantarjian H. M. \& Jones D. (2009). Imatinib mesylate dose escalation is associated with durable responses in patients with chronic myeloid leukemia after cytogenetic failure on standard-dose imatinib therapy. Blood, 113, 2154-2160. http://dx.doi.org/10.1182/blood-2008-04-154344

Kantarjian H. M., Schiffer C. \& Jones D. (2008). Monitoring the response and course of chronic myeloid leukemia in the modern era of BCR-ABL tyrosine kinase inhibitors: practical advice on the use and interpretation of monitoring methods. Blood, 111, 1774-1780. http://dx.doi.org/10.1182/blood-2007-09-110189

Martinelli G., Iacobucci I. \& Rosti G. (2006). Prediction of response to imatinib by prospective quantitation of BCR -ABL transcript in late chronic phase chronic myeloid leukemia patients. Annals of Oncology, 7, 495-502. http://dx.doi.org/10.1093/annonc/mdj106

O`Dwyer M. E., Mauro M. J. \& Druker B. J. (2001). STI571 as a therapeutic agent. In: Carella A.M., Daley G., Eaves C.J., et al. Chronic myeloid leukemia. ${ }^{\text {st }}$ edition, Martin Dunitz, 501-502.

O'Brien S., Berman E. \& Borghaei H. (2009). Chronic myelogenous leukemia. J Natl Compr Canc Netw, 7, 984-1023.

Quintas-Cardama A. \& Cortes J. (2009). Molecular biology of bcr-abl1-positive chronic myeloid leukemia. Blood, 113, 1619-1630. http://dx.doi.org/10.1182/blood-2008-03-144790

Quintas-Cardama A., Kantarjian H. \& Jones D. (2009). Delayed achievement of cytogenetic and molecular response is associated with increased risk of progression among patients with chronic myeloid leukemia in early chronic phase receiving high-dose or standard-dose imatinib therapy. Blood, 113, 6315-6321. http://dx.doi.org/10.1182/blood-2008-07-166694

Radich J. P., Zelenetz A. D. \& Chan W. C. (2009). NCCN Task Force Report: Molecular Markers in Leukemias and Lymphomas. J Natl Compr Canc Netw, 7, S-1-S-34.

Ramirez P. \& Dipersio J. F. (2008). Therapy options in imatinib failures. The oncologist. 3,424-434. http://dx.doi.org/10.1634/theoncologist.2007-0170

Sambrook J., Fritsoh E.F. \& Maniatis T. (1989). Molecular cloning: A laboratory manual. 2nd edition.

SAS. (2001). SAS User's Guide Personal Computers, SAS. Inst.Inc.Cary, N.C.USA.

Shi X., Jin Y. \& Cheng C. (2009). Triptolide Inhibits Bcr-Abl Transcription and Induces Apoptosis in STI571-resistant Chronic Myelogenous Leukemia Cells Harboring T315I Mutation. Clin. Cancer Res, 15, 1686-1697. http://dx.doi.org/10.1158/1078-0432.CCR-08-2141

Stephanie G. W., Thoral F. L. \& Shadmehr D. (2005). High-sensitivity detection of BCR-ABL kinase domain mutation in imatinib- native patients: correlation with colonel cytogenetic evolution but not Response to therapy. Blood, 106, 2128-2137. http://dx.doi.org/10.1182/blood-2005-03-1036

Thomas J., Wang L. \& Clark R. E. (2008). Active transport of imatinib into and out of cells: implications for drug resistance. Blood, 104, 3739-3745. http://dx.doi.org/10.1182/blood-2003-12-4276 
Table 1. CML patients characteristics involved in RT-RT-PCR

\begin{tabular}{|l|l|l|l|l|l|l|}
\hline $\begin{array}{l}\text { Molecular } \\
\text { response }\end{array}$ & $\begin{array}{l}\text { Patient No. } \\
(\%)\end{array}$ & $\begin{array}{l}\text { CML-phase } \\
\text { (Patient No.) }\end{array}$ & $\begin{array}{l}\text { Mean of IM } \\
\text { treatment } \\
\text { duration(ms) }\end{array}$ & $\begin{array}{l}\text { Gap in } \\
\text { treatment }\end{array}$ & $\begin{array}{l}\text { HR } \\
\text { (Patient No.) }\end{array}$ & $\begin{array}{l}\text { CyR } \\
\text { (Patient No.) }\end{array}$ \\
\hline CMR & $2(10)$ & CP(2) & 35 & No & CHR(2) & MCyR (2) \\
\hline MMR & $1(5)$ & CP(1) & 28 & No & CHR(1) & MCyR (1) \\
\hline Minor-MR & $15(75)$ & $\begin{array}{l}\text { CP (10) } \\
\text { AP (5) }\end{array}$ & 35.8 & Yes & $\begin{array}{l}\text { CHR(4) } \\
\text { PHR(7) } \\
\text { NHR(4) }\end{array}$ & $\begin{array}{l}\text { MCyR(4) } \\
\text { PCyR(11) }\end{array}$ \\
\hline No-MR & $2(10)$ & AP (2) & 37 & Yes & NHR(2) & PCyR(2) \\
\hline
\end{tabular}

$-\mathrm{CMR}=$ Complete molecular response, $\mathrm{MMR}=$ Majore molecular response, $\mathrm{MR}=$ Molecular response, $\mathrm{CP}=\mathrm{Chronic}$ phase, $\mathrm{AP}=$ Accelerated phase, $\mathrm{CHR}=$ Complete hematological response, $\mathrm{PHR}=\mathrm{Partial}$, hematological response, $\mathrm{NHR}=$ No-hematological response, $\mathrm{MCyR}=$ Major cytogenetic response, $\mathrm{PCyR}=$ Partial cytogenetic response, $\mathrm{ms}=$ months.

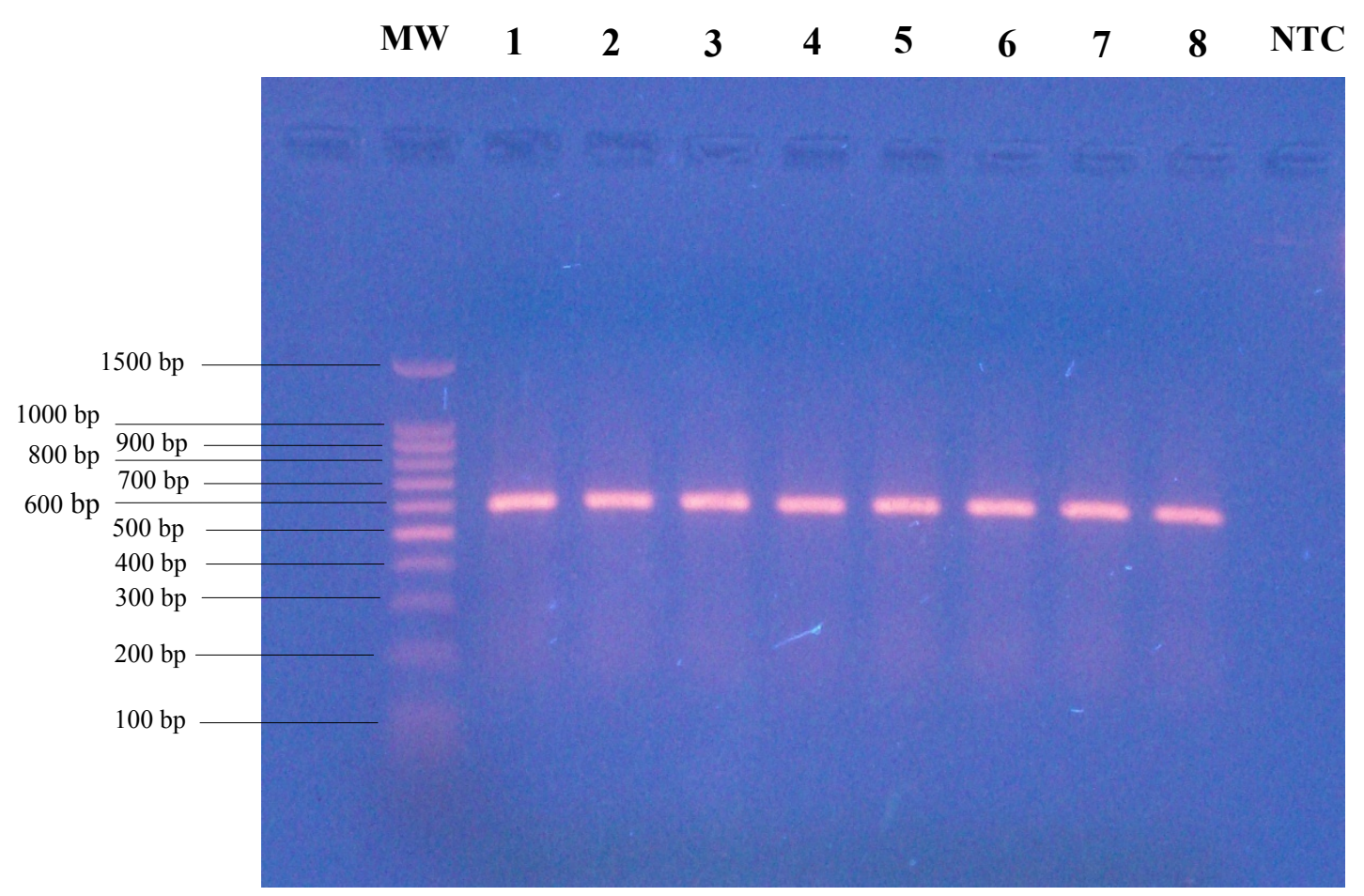

Figure 1. PCR amplified products of GAPDH gene in cDNA samples. Lane (1-8) indicated amplified products of GAPDH gene in cDNA samples related to CML patients. (MW): DNA ladder. (NTC): No template control. Electrophoresis was carried out in $1.2 \%$ agaros gel at $5 \mathrm{~V} / \mathrm{cm}$ for $60 \mathrm{~min}$ 


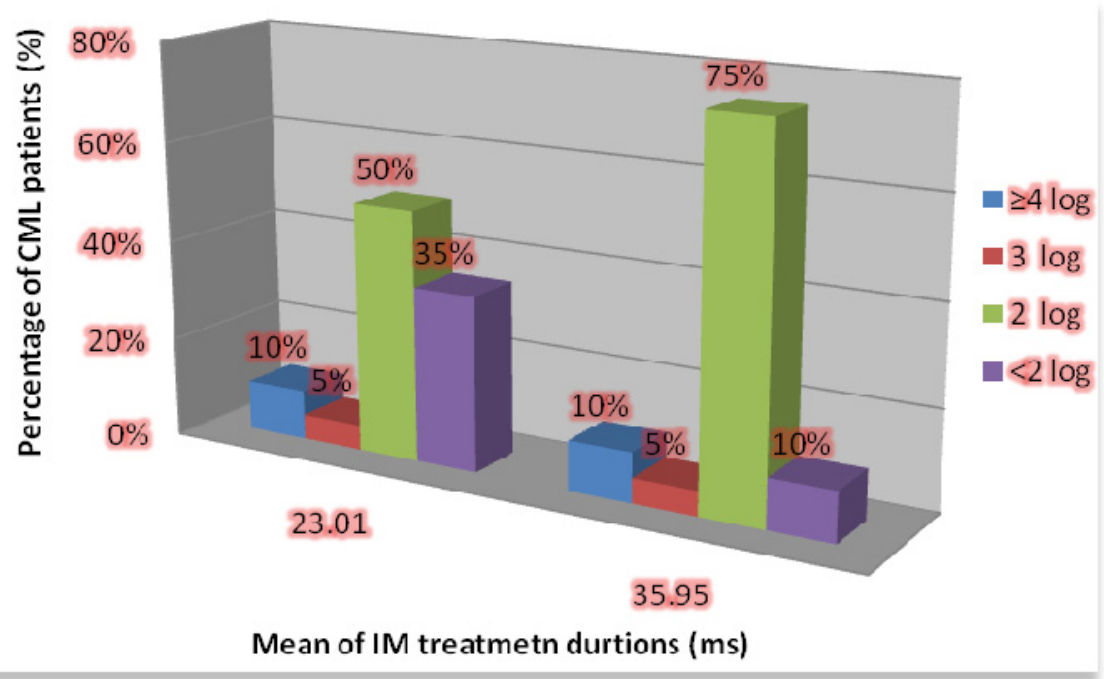

Figure 2. Log reduction of bcr-abl transcript at first and second time points of analysis 